\title{
AZ EURÓPAI KULTÚRA BÖLCSŐJÉNÉL MEGJELENŐ NEVELÉS BEMUTATÁSA KIEMELT FIGYELMET SZENTELVE A TESTI FOGYATÉKOSOK NEVELÉSÉRE
}

\author{
Szerző: \\ Hegedűs Renáta Ildikó \\ Eszterházy Károly Egyetem
}

Szerző e-mail címe:

hegedusrenataildiko@gmail.com

\author{
Lektorok: \\ Fizel Natasa (PhD) \\ Szegedi Tudományegyetem \\ Nóbik Attila (PhD, Habil.) \\ Szegedi Tudományegyetem \\ ...és további két anonim lektor
}

\begin{abstract}
Absztrakt
A tanulmányunk célja, hogy összefoglaljuk az antik görög (spártai, athéni) nevelés legfontosabb elemeit, különös figyelmet szentelve a testi nevelésre és a fogyatékossággal élő személyekre. A vizsgálat alá vont időszakban folytatott nevelési, oktatási tevékenységek bemutatásával megkíséreljük bemutatni a testi fogyatékossággal élő emberekről alkotott mentális képet, valamint megpróbáljuk szintézisbe hozni a napjainkban egyre népszerűbbé és ismertebbé váló OxIPO-modellel.
\end{abstract}

Kulcsszavak: antik görög nevelés, testi fogyatékosság, fogyatékosságtörténet, OxIPO-modell

Diszciplina: pedagógia, pszichológia

\begin{abstract}
PRESENTATION OF EDUCATIONAL PATTERNS IN THE CRADLE OF EUROPEAN CULTURE WITH PARTICULAR ATTENTION ON THE ISSUE OF THE EDUCATION OF PHYSICALLY DISABLED PEOPLE

The aim of our study is to summarize the most important components of ancient Greek (Spartan, Athenian) education, placing a special emphasis on physical education and disabled people. We attempt to present the mental picture about physically disabled people through introducing the teaching and educational activities of the observed period, moreover, we try to synthesize it with the increasingly popular and known OxIPO model
\end{abstract}

Keywords: ancient Greek education, physical disability, history of disability, OxIPO model

Disciplines: pedagogy, psychology

Hegedűs Renáta Ildikó (2020): Az európai kultúra bölcsőjénél megjelenő nevelés bemutatása kiemelt figyelmet szentelve a testi fogyatékosok nevelésére. OxIPO - interdiszciplináris tudományos folyóirat, 2020/2, 9-20. doi: 10.35405/OXIPO.2020.2.9 


\section{Az antik görög nevelés bemutatása}

Az antik görögök szerepe rendkívül kimagasló az európai kultúra fejlődésének történetében. Nietzsche gondolatmenetét idézi fel Pukánszky és Németh (1997) is neveléstörténeti könyvében:

„A görögök fokozatosan megtanulták szervezni a káoszt ... s látszatszüleségleteiket hagyták elhalni. Így vették ismét birtokba önmagukat; nem maradtak sokáig az egész. Kelet túlhalmozott örökösei és epigonjai; söt ök lettek, önmagukekal vívott súlyos küzdelem árán ... az öröklött kincs legboldogabb gazdagitóivá és gyarapitóivá, s minden eljövendö kultúrnép elsôszü̈lötteivé és mintaképeivé” (Nietzsche, 1989, 98.o.). E gondolatmenetben megjelenik, hogy értékek tömegét asszimilálták, melyeket saját kulturális értékeikkel harmonizálva rendszereztek. Ahhoz, hogy bepillantást nyerhessünk a vizsgálat alá vont időszak nevelési szokásaiba és tradícióiba szükséges ismerünk a népek történeti és földrajzi adottságait. A görögök földje egymástól elszigetelt földrajzi egységekből állt össze, ezért nagyobb államegységek kialakítására nem volt lehetőség. E feltételek azonban elősegítették és kedvező feltételeket teremtettek a poliszok (városközpontú államok) kialakulásához. A poliszok eltagolták egymástól a különböző városközpontok lakóit, így ennek köszönhetően társadalmi tagolódás kezdődött, mely a nemzetiségi törzsi keretek felbomlását vonta maga után. Az arisztokraták, vagyis a „legjobbak” irányították a közösség életét; gazdasági, politikai és vallási tekintetben egyaránt. Kialakult az arisztokratikus köztársaság. A telepedés és területszerzés szempontjából az arisztokrácia folyamatos nyomás alatt állt, rátermettségüket a területszerzés által kiváltott harcok és csaták alkalmával folyamatosan bizonyítaniuk kellett. Ezúton nyerhették el a közösség elismerését anyagi és erkölcsi téren egyaránt (Pukánszky és Németh, 1997).

Elemzésünk szempontjából fontos kitérni Homérosz görög költőre, aki Kr.e.VIII. században élt és népének kimagasló jelképé vált, akinek nevéhez füződik a heroikus emberideál mûvészi megörökítése. Eposza az Iliász a vizsgálat alá vont kor meghatározó „tananyagának” számított, ahogy a későbbiekben ugyancsak Homérosz mûvének tulajdonított Odüsszeia is.

E kor nevelési gyakorlatáról relatíve keveset tudunk. Azonban a testi erő, ügyesség és harcedzettség szükségességének nélkülözhetetlensége bizonyított, mert e képességeken múlt a háborúk sikeressége (Pukánszky és Németh, 1997).

A testi erő és edzettség fontossága egyértelműen kirajzolódik e korban, így érdemes kitekinteni a testi fogyatékossággal élő személyekre és a róluk kialakított mentális képről, mely a vizsgált korban valószínűsíthetően megjelent. Kálmán és Könczei (2002) és Magyar Adél (2017) műve egyaránt Platón és Arisztotelész szavait idézi.

E híres filozófusok is támogatóan nyilatkoztak a későbbiekben bemutatásra kerülő spártai szokásról, melyben az „élet- 
képtelennek”, „gyengébbnek” tűnő gyermeket-főként testi fogyatékosságra fókuszálva-, akik az állam fejlődését hátráltatja „eltűntetésre” ítélik.

Platón félreérthetetlenül halálra ítéli a látható testi fogyatékossággal vagy deformitással világra jött gyermeket. Platón szavai szerint: „akik csenevésznek születtek egy megközelíthetetlen, titkos helyen annak rendje és módja szerint eltüntetik" (Állam 460c).

Arisztotelész sem utasítja el a burkolt gyilkosságot és kitevést, az ő szavai: „semmiféle korcsszülöttet nem szabad fölnevelni” (Politika 1335b).

A nevelés színterén megjelenő fogyatékos gyermekről, személyről információval nem rendelkezünk. Az oktatás és nevelés során élő példával való tanítást alkalmaztak.

Az idősebbek a fiatalok készségeit ennek segítségével fejlesztették, melynek eredményeként az idősek feltétel nélküli tiszteletnek örvendtek. Az elsődleges nevelési színtér a család volt, az édesanya számított első nevelőnek, de a lányok nevelése ennél nem is fejlődött tovább. A korábban említett költeményekből egyértelmú, hogy a ház körüli teendők ellátása alapvető „követelménynek” számított, míg a legfőbb erkölcsi erényüknek az állhatatosság és a kikezdhetetlen házastársi hűség számított (Pukánszky és Németh, 1997). A továbbiakban a spártai és az athéni nevelés részletesebb bemutatása következik.

\section{A spártai nevelés}

A dór törzsek egy része a hódító „spártaiak" a hegyek és mocsaras vidékek által övezett zárt területen telepedett meg. A helótákat, az ott lakó őslakosokat rabszolgasorsba és jogfosztottságba kényszerítve. A katonai arisztokrácia ragadta magához az uralmat; hatalmuk a Lükurgosznak szentesített törvényein alapult. A törvény nevelésre vonatkozó részre meghatározza, hogy a gyermekeiknek egységes állami nevelésben kell részesülniük. A nevelés elsődleges célja az állandó harci készültség fenntartása - ekkor Spárta már felvette a későbbiekben ismert katonai arculatát (Pukánszky és Németh, 1997). Azonban azt egyöntetűen eldönteni, nem lehet, hogy ez a nevelési rendszer mikor keletkezett. Prohászka (2003) írásában valószínűsíthetőnek tartja, hogy a VIII. század végén, illetve a VII. század elején. Spártában az uralkodói pozíció megvédése miatt kíméletlen harcosok formálása volt a cél. Erre szükség is volt, mivel az uralkodó osztály tagjainak száma 8 ezer körüli létszámon mozgott, szemben a helóták állandó lázadásban élő 200 ezres tömegével. Ez a nevelés együtt járt az egyéniség teljes elfojtásával (Pukánszky és Németh, 1997). Plutarkhosz a Párhuzamos életrajzok címú írásában arra utal, hogy a város olyan képet fest, mintha katonai tábor lenne. Minden polgár a poliszért él és nem önmagáért. E szavakból kitűnik, hogy a spártai harcost az alábbi három dolog jellemzi: testi erő, edzettség, fanatizmus. A fellelhető antik forrásokból kiderül, hogy 
Spárta az állandó harckészültségben lévő tábor képét mutatta. Ezért a katonai nevelés jellegét kétségbe vonni nem lehet (Prohászka, 2003).

E jellemzők mentén érdemes megvizsgálni, hogy a vizsgálat alá vont korban megjelenik-e a testi fogyatékosság jelensége és amennyiben megjelenik, milyen mentális kép alakult ki e fogyatékossággal élő személyekről. Plutarkhosz korábban idézett múvében utal arra is, hogy megjelenik a testi fogyatékosság. Elsősorban az „idétlen” és „nyomorék” jelzővel társították. E személy nem előnyös sem a gyermeknek, sem az államnak. Ahogyan Plutarkhoszra utal Kálmán és Könczei (2002) és Magyar (2017) is, ismeretes a Spártában kialakult hagyomány a Lükurgosz korában, amit a szerzők a fogyatékosan született gyermekek intézményes segítésének ellentéteként fogalmaztak meg: „Az újszülött csecsemövel apja nem rendelkezett, hanem karjába vette és elvitte a Leszkhé nevü helyre, ahol a törzsek vénei összegyülekeqtek, és megvizsgálták a kisdedet. Ha egészséges alkatú és eröteljes csecsemö volt, utasitották az apát, hogy nevelje fel, egyben pedig kijelöltek neki egyet a kilencezer spártai parcellából. De ha idétlen vagy nyomorék volt, bedobták a Taigetosz. Apothetai nevü szakadékába - azzal a meggyözódéssel, hogy nem elönyös sem a gyermeknek, sem az államnak, ha egy születésétöl kequdve gyenge és életképtelen ember életben marad. Ezért fürdették meg az asszonyok az üjszülöttet borban és nem vízben, hogy kipróbálják szervezete állóképességét. Ha ugyanis epilepsziás vagy gyenge, beteges szervezetü volt a gyermek, görcsöt kapott az erös bortól, és elpusztult, de ha egészséges volt, még irmosabb lett.” (Lükurgosz, 16, 1-3. - Máthé Elek ford.) (Kálmán és Könczei 2002) A spártai gyakorlat nem számított egyedinek, nem csak itt volt bevett gyakorlat a gyermek eltávolítása. Azonban az elterjedt nézetekkel szemben nem dobták le a nem kívánt csecsemőket. Csupán a Taygetos hegy Apothetai nevü helyén kitették. A kitett csecsemők gyermektelen családokhoz, rabszolgakereskedőkhöz vagy kerítők kezébe is kerülhettek (Hoffmann, 2009). Magyar (2017) szerint, ha a gyermek a kitevést elkerülte, akkor a borban fürdetés szokása a spártai gyermek első igazi nagy fizikai próbatétele. Az életben maradás nem az istenek vagy a „törzsek vénei” döntéshozatalától, hanem a testi adottságaitól, képességeitől függött. E „gyermekszelekció" gyakorlatának szélesebb körben történeti kontextusba helyezése érdekében megjegyzi azt is, hogy Spárta egyetlen városállamként múködött, ahol a törvények szabályozták a gyerekek kitevését. Ennek megfelelően egy testület, vagyis a „törzsek vénei”, hoztak határozatott a gyermek jövőjéről. Magyar Adél (2017) a korabeli mentalitást bemutatva utal a posztnatális születésszabályozásra, vagyis a szülés utáni gyermekszelekcióra. E téma az általános pedagógiatörténeti és gyermekkortörténeti szakirodalomban is népszerü. Kiemeli, hogy az újszülött kitevését vagy a hasadékba dobását megelőzte az a szokás, hogy a gyermeket apjának bemutatták és annak joga volt 
arra, hogy ne fogadja el. Spártában a polisz véneinek volt joga hasonlóan az apa jogaihoz, vagyis dönteni a gyermek jövőjéről. Más eltérő korokban és kultúrákban alkalmazott áldozat „bemutatás" is hasonlóan működött, mely leginkább az elsőszülött gyermekekre vonatkozott. Ezek elsősorban a poliszok és lakóik védelmében alakultak ki. Christina Tuor-Kurth svájci teológus általános „kulturális jelenségnek” tekinti a csecsemők elpusztítását és kitevését a korabeli társadalmakban. A leggyakoribb indokok közé sorolja általánosságban a szegénységet és ehhez kapcsolódóan a szegény családokba született sok gyermeket, a tehetősebb szülők kényelemszeretetét, a gyenge fizikumot és testalkatot és a látható testi fogyatékosságot. Továbbá utal arra a bűntudatra és szégyenérzetre, mely a szülőkben alakulhatott ki a kitevést és gyilkosságot követően (Tuor-Kurth, 2010, 16-17.).

A spártai nevelés és életmód már az ókorban is a maga módján egyedülállónak számított. Főként az erōs közösségi szellem kiépítésére és fenntartására való törekvés miatt (Hoffmann, 2009). Spártában a családi nevelés egészen hétesztendős korukig terjedt, ekkor kerültek a közös nevelés színterére, vagyis táborokba, melyben csoportokra osztották őket, élükre a legrátermettebb és legértelmesebb fiúkat tették. Mezítláb jártak, hajukat lenyírták, tizenkét éves koruktól mosdatlanul ugyanabban a köpenyben kellett járniuk (Pukánszky és Németh, 1997).
Összességében elmondható, hogy katonai táborokban élték életüket a 7-30 éves koruk között lévő fiúk s férfiak egyaránt, korcsoportos felosztás szerint. E felosztás elsősorban a megfelelő oktatás és kikép-zés kiválasztása miatt volt fontos. A spártai férfi napjait 30 éves kora után is táborokban töltötte, de már alapíthatott önálló háztartást (Hoffmann, 2009).

A nevelés legfőbb célja, hogy megtanulják az elöljáróiknak való fegyelmezett engedelmességet, jól tưrjék a testi fájdalmakat, és a harcban bátran helytálljanak. Ahogyan azt Pukánszky és Németh (1997) is hangsúlyozzák művükben a szellemi képzettségre nem, de a testi edzettségre kiemelt figyelmet szenteltek a spártaiak. Szi-gorú fegyelem uralkodott nevelésükben és gyakoriak voltak a büntetések A férfivá válást különböző beavatási szertartásokkal kötötték egybe. Erre elsősorban 17 esztendős korukban kerülhetett sor. E beavatás során akár megkorbácsolásra is sort keríthettek. E beavatás sikeressége azon múlt, hogy a csendben sikerült-e tűrnie a jelöltnek, ha ezt nem sikerült véghezvinnie, akkor még nem tekintették férfinek (Hoffmann, 2009).

Szervezetüket folyamatosan edzették, nehezedő erőpróbák elé állították a gyermekeket. A szigorú testi nevelésen túl csak minimálisan jelenik meg az értelmük képzése. Gondolataik szabatos, világos és érthető módon való kifejezése szükségszerű, azonban az írás olvasás elsajátítása nem. A költészet és zene sem számított 
szükségszerűnek csak olyan műveket sajátíthattak el, ami az elszántság, lelkesedés, bátorság fokozását és az erkölcsök nemesítését segítették elő és az állam dicsőítését szolgálta.

Az erkölcsi nevelés során, mint követendő érték a fegyelem, a hazaszeretet, az idősebbek tisztelete és az engedelmesség jelenik meg (Pukánszky és Németh, 1997). A feltétel nélküli engedelmességet a feljebbvalójuk iránt gyakorlat által is bizonyították. Rejtőzködésnek, túlélési gyakorlatnak titkos megbízatásnak is nevezték. A gyakorlat lényegében kegyetlen „mészárlás” volt nemre és korra való tekintet nélkül. E folyamat során az idősebb fiúk becserkészték, majd megrohamozták a rabszolgák táborát. E gyakorlatok célja kettős szándékú: megrettenték és folyamatos félelemben tartották a rabszolgákat, valamint erkölcsi aggályoktól mentes kegyetlen viselkedésre szoktatták a fiatalokat. A hadsereg kitűnően képzett tagjaivá húszéves korukban váltak.

Ebben a korban megnősülhettek, de még tíz esztendőig a kaszárnyákban kellett élniük. A családjukhoz költözést követően egészen hatvanesztendős korukig katonakötelesek maradtak. A fiúk nevelés mellett a spártaiak érdeméhez sorolható, hogy a lányok nevelését is szívügyüknek tartották. Azonban az ő nevelésük elsődleges célja az volt, hogy a jövendő gyermekeik erős, egészséges és edzett testben foganhassanak meg. Szinte azonos képzésben vettek részt, megtanultak futni, birkózni, dárdát hajítani és diszkoszt vetni. Ezek- nek az elsajátítására továbbá azért is volt szükség, mert a hadjáratok idején az otthon védelmének faladata a „gyengébbik” nem képviselőire hárult.

Összességben elmondható, hogy egy befelé forduló, állandó készenléten alapuló pedagógiai rendszer volt jelen a spártaiaknál, melyben a testi nevelés programja kiemelt szerepet kapott. A görög kultúra sarkítása lenne, ha nem említenénk meg az athéni nevelést, mely számos tekintetben eltér a spártaitól, illetve kiegészítette az általuk képviselt nevelési gyakorlatot (Pukánszky és Németh, 1997).

\section{Az athéni nevelés}

Ahogyan arra már utaltunk az előző fejezet végén a spártai és athéni nevelés eltérő mederben folytak. Thuküdidész A peloponnészoszi háború című könyvében Periklész. kiváló athéni államférfi szavait idézi: „Az ő nevelésüket az jellemzi, hogy már kora ifjúságuktól fogva szüntelenül fáradságos gyakorlatokeal edzik magukat a férfias helytállásra, mi viszont szabadabb módon élünk, de nem csekélyebb elszántsággal tudunk ugyanolyan veszélyekekel szembenézni... S h ami inkább könnyedebb életmóddal, mint fáradtságos gyakorlatokekal, és nem a törvények által belénk oltott, hanem elsösorban velünk sqületett bátorsággal készülünk a veszedelmek leküzdésére, ez azzal az elönnyel is jár, hogy nem izleljük meg már elöre a még csak közelgö megpróbáltatásokat ha viszont már bennük vagyunk, nem tanúsitunk kisebb hösiességet azoknál, akiknek egész élete fáradozásban telik"” (Thuküdidész,1985,187188. o.). 
E sorokból következtethetünk arra, hogy az athéniak a nevelés által kívántak olyan harmóniára törekvő és harmóniában élő embert faragni, akik értelemi képessége, erkölcsi érzéke, szépség iránti fogékonysága mellett a bátorsága is kimagasló, ezáltal felvehette a versenyt a spártai harcossal amennyiben a szükség úgy hozza.

Athén politikai helyzetét tekintve előnyösebb helyzetben volt, mint a spártaiak, mivel a jogokkal nem rendelkező betelepültek - metoikoszok - és a rabszolgák nem voltak nagy létszámú fölényben, mint a korábban bemutatott Spártában. A polisz élén a hellén születésű arisztokraták és a jómódú - legmagasabb jövedelemmel rendelkező - polgárok álltak. A rabszolgák nem rendelkeztek semmiféle jogokkal, „beszélő szerszámoknak” tekintették őket. A legkiválóbb állami vezetők - mint például Drakón, Szolón vagy a korábban már említett Periklész - a kultúra és a művészetek fejlődését és kiterjesztését is támogatták, jelentős áldozatokat hoztak, hogy a „démosz”, vagyis a nép számára is elérhető legyen. A spártai neveléstől eltérően, bár törvényi, központi szabályozás nem érvényesült, mégis mindenki ,igénybe vehette" az oktatást. A vagyonosok igyekeztek „jó poliszpolgárokat” létrehozni. A jó poliszpolgárt a szakmai és általános műveltség jellemezte. A szakmai mûveltség elsajátításához szükséges készségeket és ismereteket a szülők hagyományozták gyermekeikre, apáról fiúra szállt a mesterség. Az általános műveltség átörö- kítése a dajka, az anya, a nevelő és az édesapa által egyaránt biztosított volt. A közéleti szerepléshez szükséges készségek elsajátításáról beszélhetünk. A népének történelmét, klasszikus írók és költők műveit, a mitológia mondáit is ismernie kellett. A múvelt ember határozott elképzeléssel rendelkezett, érvelő logikus gondolkodásmód jellemezte, okfejtésben, vitában részt tudott venni. A családi nevelést követte hét esztendős korban a magántanító. A képzés összetevői két részből álltak: múzsai képzés és gimnasztikai képzés. A múzsai képzésben megjelent: a) a grammatikai-irodalmi képzés, melybe az olvasás, írás, számolás tanulás és irodalmi múvek tanulmányozása is beletartozott továbbá b) a kithara-képzés melyhez a hangszerjátékkal kísért énekelt versek tanulása és a tánc sorolható. Az athéni nevelésben különböző iskolatípusok is megjelentek. Melyek a következők: grammatikai ,iskola”, kithara-,,iskola”, palaisztra, gümnaszion (Pukánszky és Németh, 1997). Jelen tanulmány szempontjából a testi neveléshez kapcsolódó iskolák bemutatására térek ki. A palaisztrában vagyis birkózásra kijelölt helyen a gyermekek hétéves koruktól kezdve kezdték meg gimnasztikai képzést. A képzés elsősorban a tornatanításra és a testgyakorlásra korlátozódott (Pukánszky és Németh, 1997). Paidotribésznek vagy gümnasztésznek hívták a testgyakorlás tanítóját. A testgyakorlatokat zenei kíséret mellett, meztelenül végezték a fiúk. A testgyakorlatok között fő szerepet kapott a futás és a birkó- 
zás; továbbá alárendelt tevékenységként az ugrás, a diszkosz- és a gerelyvetés is megjelent (Prohászka, 2003). A testgyakorlást az idősebbek a gümnaszionban folytatták. Az épület fedetlen és fedett futópályákból állt, továbbá vetkőzésre, tisztálkodásra szolgáló szo-bák is kialakításra kerültek. A későbbiekben az előadótermek és a könyvtárak is megjelentek (Pukánszky és Németh, 1997).

A lány és nőnevelés lényegesen szegényesebb körülmények között folyt és csak minimális tevékenységekre és készégekre koncentrált. Leginkább a háztartási, gazdasági ismereteket, valamint a varrás, kötés, fonás és szövés tevékenységeket. Olvasni és írni is csak valamelyest tanulhattak meg szüleiktől vagy dajkájuktól. A politika világa tiltott volt számukra. Legfőbb erényük a hallgatás (Pukánszky és Németh, 1997). Pukánszky Béla a nőnevelés évezredei című könyvében részletesebben ír erről, de a nőnevelés történetének tanulmányozása szorosan nem kapcsolódik a jelen kutatásunkhoz, így ennek bemutatását mellőzzük.

Jól látható, hogy az athéniak is kiemelten kezelték a testi nevelés kérdését. A „kalokagathia” elvét követték, mely szerint „szép” és a „jó” harmonikus egységben létezik. Elsődleges céljuk ellentétben a spártaiakkal nem a harcedzett katonák képzése, hanem az esztétikus és harmonikus test kialakítása. A testi nevelés során a fizikum formálódás erősödése mellett fejlődésnek indul az akaraterô, az önzetlenség, az önfeláldozás erénye. Eszményük- ben az egyszerű ember él, aki képes hőssé válni, ha a szükség úgy kívánja. A spártai nevelés esetében jól érzékelhetően a fizikai kényszer uralkodott, míg az athéniak hittek abban, hogy a gyermeki lélekbe mélyebben is be lehet hatolni és ehhez az esztétikumot hívták segítségül (Pukánszky és Németh, 1997; Fináczy, 1906).

Az ókori nevelés története című könyvében kiemeli, hogy nem csak az irodalom, a zene vagy a testgyakorlás során találkozhatott a gyermek az esztétikummal, hanem az őt körülvevő természet, szülői ház vagy akár a fenséges templomok is ezt az üzenetet közvetítették. Kálmán és Könczei (2002) a Taigetosztól az esélyegyenlóségig című könyvükben említenek olyan képzőmûvészeti alkotásokat, melyek pontosan rögzítették a súlyos olykor maradandó fizikai sérülés vagy akár egyéb belső szervi elváltozás lehetőségét. Ezek a képzőművészeti alkotások elsősorban a nehéz fizikai munkától való sérülésre utalnak, azonban a perzsákkal való háborúskodás eredményeképp a fogyatékossá válás a harcedzett katonákat is érinthette. Azonban a csatában súlyos sérülést szenvedett harcos nem a mellőzés vagy kirekesztettség sorsára jutott. A hőst, aki hazájának céljaiért küzdve tett szert sérülésre vagy fogyatékosságra köztisztelet és közmegbecsülés övezte Spártában. Hérodotosz görög történetíró műveiben számos fogyatékosságról tesz említést. Emellett fontos kiemelni, hogy e görög kor kultúrájában nem társították automatikusan a fizikai fogyatékosságot a jellembelivel. 
Spártától eltérő módon görög földön, ahogyan arra korábban már utaltunk az újszülött kitevését vagy a hasadékba dobását megelőzte az a szokás, hogy a gyermeket apjának bemutatták és annak joga volt arra, hogy határozzon gyermeke sorsáról, mely a felnevelés vagy kitevés lehetett. Ebből következtethetünk arra, hogy a gyermekek „szelektálása” szerves része a görögök mentalitásának. Leginkább kitevés formájában valósult meg. Hasonló következtetést von le Magyar (2017) is, valamint utal Platón és Arisztotelész gondolatmenetére.

\section{A testi fogyatékosság meghatározása}

Jelen tanulmányunkban az antik kor nevelési szokásait igyekeztünk bemutatni, kiemelt figyelmet szentelve a testi fogyatékosok nevelésére. A rendelkezésünkre álló forrásokból következtethetünk arra, hogy miként írták le a testi fogyatékosságot. Leginkább a „nyomorék” és ,idétlen” szavakkal jellemezték, de ezeket a „leírásokat" a mai korban alkalmazott fogalmakhoz viszonyítani nem lehet. Annak ellenére sem, hogy a testi fogyatékossággal élők megjelentek a vizsgált korban, feltételezhetjük, hogy az ilyen típusú sérülésekkel rendelkezőket nem részesítették oktatásban és nevelésben, mivel a társadalom problémájának tekintették. Nehezen elképzelhető, hogy az egyéni nehézségek és problémáknak megfelelő oktatást biztosítottak számukra, melyeket ma már törvényi szinten is biztosítottak. E gondolatmenet alapján életszerűtlen, hogy fel- mentenek a testi nevelés során egy spártait gyenge fizikumára vagy egészségi állapotára való tekintettel.

Továbbá következtethetünk arra, hogy a halálra ítélés egy testi fogyatékossággal született gyermek tekintetben nem egyedülálló eset. Az athéni nevelést vizsgálva arra következtethetünk, hogy ahol az esztétikum kiemelt szerephez jut, ott sem feltétlenül „férhetett meg” a torzult, sérült fogyatékos test megjelenése. Valószínúsíthető, hogy negatív mentális kép alakult ki az adott korban a testifogyatékosok gyermekek és felnőttek esetében egyaránt.

\section{Az OxIPO modellre való illesztés lehetőségeinek feltárása}

A OxIPO-modellt - Teljesítmény = Organizáció x (Input x Process x Output) - és annak elődjét az IPOO modellt és fogalmát egyaránt Mező Ferenc (2011, v.ö.: Mező és Mező, 2019) vezette be. E modell napjainkban egyre népszerűbb. Ahogyan arra Tudlik (2019) is utal Mező annak leírására törekszik, hogy a tanulók hogyan szerzik, dolgozzák fel, szervezik és produkálják ismereteiket a tanulás, teljesítmény és tanulásmódszertan terén.

Neveléstörténeti szempontból - ahogyan erre Mező és Mező (2019) felhívja a figyelmet - érdekes kutatásokat lehetne végezni, hogy mely korokban, milyen tartalmat milyen módszerrel adtak át, miként történt ezen értékek ellenőrzése. M. Pelesz és Szűts-Novák (2019) neveléstörténeti kutatása pozitív példa arra, hogy 
szintetizálni lehet a modellt a neveléstörténettel.

Athénban és Spártában is szervezett nevelésről számolnak be a források. Egyértelműen kirajzolódik, hogy kiemelt figyelmet szenteltek a testi nevelésre. Az elsődleges céljuk azonban eltérő volt. Spárta katonaállam, melyben senki nem élhet önmagáért csak az államért. A tesi nevelés pedig az állam érdekeit szolgálta. Athén rendszere lényegesen különbözött a spártai berendezkedésétől. Nevelésük fő célja, hogy az emberi test széppé, arányossá és erőssé váljon. A „kalokagathia” eszményének megvalósításán kívül azt vallották, hogy a test a lélek lakóhelye, így ennek különösen szépnek kell lennie. Másodlagosan megjelent a katonai szolgálatot teljesítő embertől elvárható erős és izmos test, de ez nem nyilvánult meg olyan mértékben, mint a spártai gondolkodásban. Az egészséges és szépen kimunkált test arányos tagokkal rendelkezik. Az ilyen adottságokkal rendelkező személy, mozdulatai könnyedek, mozgása harmonikus, ritmusos. Megjelenésében kellemes és szép látványt nyújt (Hoffmann, 2009). Az eltérések ellenére mindkét államban megjelenő nevelési elemeket az OxIPO modell alapjainak is tekinthetjük. Az OxIPOmodellre illesztve a társadalmi közeget és képzési formákat tekinthetjük organizáció részének. Inputként értelmezhetjük azokat az ingereket, ismereteket és módszertani fogásokat, amelyekkel a korai gyermeknevelés, a családi és a későbbi nevelés során találkoztak a fiatalok. Pro- cessként tekinthetünk az input során szerzett információk kognitív-emocionális feldolgozásának folyamtára. A tanulási folyamat végén jelentkező outputként tekinthetjük szúkebb (oktatási) értelemben a tanulás során elsajátított ismereteket és készségeket, tágabb értelemben (nevelési kontextusban) pedig a „tökéletes harcost”, a „heroikus”, hősi áldozatokat vállaló embert, az kor eszméjét tükröző módon ideálisnak tekintett asszonyt, vagy legalábbis az antik görög emberképhez közelíteni kívánó személyt.

Összességében elmondható tehát, hogy a vizsgált korszakban megjelent az oktatás és nevelés. A nevelés terén kiemelt szerepet kapott a testi nevelés. A nevelés kérdéseit azonban érdemes bemutatni és különböző szempontok alapján megvizsgálni.

\section{Összefoglalás}

A tanulmányunk során összefoglaltuk az antik görög (spártai, athéni) nevelés legfontosabb elemeit, különös figyelmet szentelve a testi nevelés kérdésére és a testi fogyatékossággal élő személyekre. Ennek okán bemutatásra kerültek a vizsgált korban megjelenő a testi fogyatékossághoz kapcsolódó fogalmak. A vizsgálat alá vont időszakban folytatott nevelési, oktatási tevékenységek bemutatásával megkíséreltük bemutatni a testi fogyatékossággal élő személyekről kialakított mentális képet, valamint megpróbáltuk szintézisbe hozni a napjainkban egyre népszerűbbé és ismertebbé váló OxIPO-modellel. 


\section{Köszönetnyilvánítás}

A tanulmány az Eszterházy Károly Egyetem az EFOP-3.6.1-16-2016-00001 „Kutatási kapacitások és szolgáltatások komplex fejlesztése az Eszterházy Károly Egyetemen” projekt támogatásával jött létre. A támogatást ezúton is köszönjük!

\section{Irodalom}

Arisztotelész (hazai kiadás: 1994): Politika. Gondolat kiadó, Budapest.

Fináczy Ernő (1906): Az ókori nevelés története. Magán kiadás. Budapest.

Hoffmann Zsuzsanna (2009): Antik nevelés. Iskolakultúra-könyvek 35. Veszprém.

Homérosz (hazai kiadás: 1981): Iliász, XIX. ének. Budapest, 45.

Homérosz (hazai kiadás: 1974): Odüssz̨eia. Budapest.

Kálmán Zsófia, Könczei György (2002): A Taigetosztól az esélyegyenlóségig. Osiris Kiadó, Budapest.

M. Pellesz Nelli, Szűts-Novák Rita (2019): A Pedagógiai és Lélektani Intézet 1929-es megalapítása, szellemi előzményei és működésének első évtizede - Imre Sándor és Várkonyi Hildebrand Dezső tevékenysége. OxIPO - interdiszciplináris tudományos folyóirat, 2019/2, 9-24. doi: 10.35405/OXIPO.2019.2.9

Magyar Adél (2017): Fejezetek az értelmifogyatékosság-kép történetéböl Elzárás, gyógyitás, fejlesztés a kezdetektöl a 19. század végéig. Gondolat Kiadó, Budapest.
Mező Ferenc (2010): A gondolkodás jellemzői, vizsgálati és fejlesztési lehetőségei. In Pšenáková Ildikó, Mező, Ferenc (szerk.)(2010): Képességfejlesztés digitális tananyaggal. Kocka Kör, Debrecen

Mező Ferenc, Mező Katalin (2015) A sajátos nevelési igényü (SNI) gyermekek tehetségének egyéni mentorálása. Tebetség 2. 3-5.

Mező Ferenc és Mező Katalin (2019): Az OxIPO-modell-az interdiszciplináris kutatások egy lehetséges értelmezési kerete. OxIPO- interdiszciplináris folyóirat, 2019/1, 9-21. doi:

10.35405/OXIPO.2019.1.9

Nietzsche, F. (1989): A történelem hasznáról és káráról. Akadémiai Kiadó, Budapest.

Platón (hazai kiadás: 1983): Az állam. In: Platón válogatott múvei. Európa Kiadó, Budaapest.

Plutarkhosz (hazai kiadás: 1978): Párbuzamos életrajzok. Magyar Helikon, Budapest..

Prohászka Lajos (2003) Az európai ókor neveléstörténete. In Orosz, G. (szerk.) Az európai ókor neveléstörténete. Prohászka Lajos egyetemi elóadásaiból I. Debreceni Egyetem Bölcsészettudományi Kar Neveléstudományi Tanszék, Debrecen.

Pukánszky Béla (2006): A nônevelés évezredei. Gondolat Kiadó, Budapest.

Pukánszky Béla, Németh András (1997). Neveléstörténet. Nemzeti Tankönyvkiadó, Budapest.

Thuküdidész ( hazai kiadás:1985): A peloponnészoszi háború. Európa, Budapest. 
Tudlik Csilla (2019): Akadályozottság, sajátos nevelési igény és pályaválasztási algoritmus az IPOO modell alapján. OxIPO-interdiszciplináris tudományos folyóirat, 2019/1, 61-73. doi: 10.35405/OXIPO.2019.1.61
Tuor-Kurth, C. (2010): Kinderaussetzung und Moral in der Antike. Jüdische und christliche Kritik am Nichtaufriehen und Töten neugeborener Kinder. Vandenhoeck \& Ruprecht, Göttingen. 